\title{
Reconciling community land and state forest claims in Indonesia: A case study of the Land Tenure Settlement Reconciliation Program in South Sumatra
}

\author{
M. Nazir Salim ${ }^{1, *}$, Diah Retno Wulan², Sukmo Pinuji ${ }^{1}$ \\ 1 National Land Institute (STPN) \\ 2 Staff of Secretariat General of Ministry of Agrarian Affairs and Spatial Planning/National Land Agency \\ * Corresponding author: nazirsalim2011@gmail.com ; phone: +628112652235
}

\begin{abstract}
Longstanding land tenure claims in state forest by communities continues to pose a challenge to government institutions in Indonesia. Such conditions require institutions to develop mechanisms to assure communities of their rights in the state ideals of manifest justice and welfare. One government policy to reconcile these goals is the mechanism on Land Tenure Settlement Reconciliation in State Forests (Penyelesaian Penguasaan Tanah dalam Kawasan Hutan/PPTKH). This study aims to describe this policy in the context of fieldwork experience related to fundamental problems in the process of identification and settlement of land tenure claimed by communities in state forests. Data collection was obtained through participant observation conducted with communities in Ogan Kemoring Ulu Regency by identifying and verifying community lands in state forests. This method allowed for a more nuanced understanding of settlement challenges and afforded the opportunity to develop a formula for addressing conflicts. The results of the study show that the main problems are a lack of access to information related to the PPTKH policy emergent from ineffective dissemination of information combined with an underdeveloped capacity of processes that support the community to convene and discuss with government actors, academics/researchers, and activists/scholars. The participative learning process conducted by the authors helped the community effectively prepare documents to propose to an Inventory and Verification (Inver) team of Land Tenure in State Forests. Therefore, going forward more collaborative work is needed within the framework of community assistance and capacity building so that the communities have the means and resources to able to understand the challenges of land tenure recognition and be empowered to propose such mechanisms independently. Communities who claim land in state forests depend upon formalized legality, without which can potentially harm their access and assets.
\end{abstract}

Keywords: Agrarian Reform; State forests; PPTKH; PTKH Inver; Participative learning

\section{Introduction}

The National Agrarian Renewal Program (Program Pembaruan Agraria Nasional, or PPAN), as a land redistribution policy rolled out in 2006-2007 was supposed to reach state forests as part of a broader initiative to address land redistribution on state lands, in conversion forest, and with regard to abandoned land objects (Rachman, 2012: 102-104). Unfortunately, PPAN implementation could not extend to state lands because there was limited support from key ministries, particularly at that time, the Ministry of Forestry (Luthfi, 2018, 143). Agrarian reform began to reach state forests (especially related to community lands in state forests) only after the Alliance of Indigenous Peoples of the Archipelago (Aliansi Masyarakat Adat Nusantara, or AMAN) representing indigenous peoples groups won a lawsuit on several articles in Law No. 41 of 1999 (Siscawati, 2014). This Constitutional Court Verdict No. 35/PUU-X/2012 confirmed that Customary Forests are a forest category that is within the territory of indigenous people and can no longer be categorized under the definition of state forests (Rachman, 2014; Wibowo, 2019). The Constitutional Court Verdict was followed by a policy that sought to exclude indigenous peoples' lands in state forests through an inventory mechanism of community land tenure in state forests.

In response to the Constitutional Court Verdict 35/2012, in 2014, a Joint Regulation of Minister of Home Affairs, Minister of Forestry, Minister of Public Works and Head of National Land Agency, 
was passed. Known as the Perber 4 Menteri, the regulation would facilitate policies related to settlements of land tenure claimed by communities within state forests. Perber 4 Menteri was constrained because the legal product was considered insufficient, and thus endeavored to scale the decision up to a Presidential Regulation (Wibowo et al., 2017). In 2017, this Presidential Regulation No. 88/2017 entitled the Settlement of Land Tenure in State forests (PPTKH) was issued as a legal umbrella that bound various sectors to address the challenges concerning community claims to secure land tenure in state forests.

The Presidential Regulation 88/2017 argument was based on the fact that a large number of land tenure conflicts in state forests claimed by communities had not been settled and continued to result in conflict. These are mostly lands that community claim rights to long before the establishment of state forests, even before the Republic of Indonesia became an independent state. Data from the Ministry of Environment and Forestry (Kementerian Lingkungan Hidup dan Kehutanan, ok KLHK) states that there are about 25,863 villages in and around state forests or otherwise amounting to 9.2 million households (Winata, 2019; Sutaryono et al., 2018; Sirait, 2017). Previously, a survey of the Central Statistics Agency (Badan Pusat Statistik, or BPS) in 2014 recorded that there were 2,037 villages within state forests, or 19,247 villages around state forests, with the remaining 60,906 villages outside of state forests (BPS, 2014). Even though the figures above may differ from one another, the larger point is that there are a large number of villages and community lands located in state forest, which often lead to contested claims and an impetus for government institutions to help resolve them.

The existence of communities in state forests requires attention because when local claims to tenure do not obtain legal certainty, they can result in conflicts (Irawan et al. 2016; Rozi et al., 2018), which include challenges relating to claims made by indigenous peoples who demand recognition of their rights (Fisher et al., 2017; van der Muur, 2018; Mary et al., 2013). Such claims not only take place on limited production forests and protection forests lands, but also among buffer zones and conservation forests (Hein et al., 2016).

If left unaddressed, overlapping community and state claims can cause problems, especially if key assets are rendered into different structures of authority, limiting access to resources. This can also refer to broader forms of governance and management, in the form local informal institutions (Utami et al., 2018). Taken together, differences of authority and access can lead to conflicts and criminalization of peoples' access to land in state forests (Rachman, 2014). Therefore, the change of boundary setting through land tenure in the State Forest Inventory and Verification initiative (or PTKH Inver), particularly related to the collective application mechanism from the community becomes a program that has particular urgency. Of course, a large-scale public outreach initiative must also be undertaken in parallel at the site, which requires dimensions of both top-down and participatory engagement so that people can gain the knowledge about how the policy works while also increasing their capacity to carry out the institutional measures to secure their rights (Seixas et al., 2009; Pujo et al., 2018).

The impetus for settling claims was taken on by KLHK through the Director General of Forestry Planning by issuing a policy to resolve tenure conflicts in state forest by setting priority locations to be targeted by the PPTKH. In 2017, as many as 159 regencies/cities from 26 provinces were set as the targets of PPTKH implementation with a target area of 1,690,327 hectares (Tim Pelaksana PPTKH, 2017, 10; Salim \& Utami, 2019). In the same year (2017-2018) the Inver Team was formed by governors of 26 provinces, chaired by the Provincial Forest Service and fully supported by the State Forests Consolidation Center (Balai Pemantapan Kawasan Hutan, or BPKH). To expedite the settlement efforts, in May 2018 the Minister of Economic Affairs Regulation No. 3/2018 provided a guide for carrying out identification and inventory of community land in state forests. Since the Ministerial Regulation was issued, Inver activities were then carried out quickly in various districts and provinces, and signifiant progress was made through the end of 2019, showing the boundaries of community-controlled state forests for 24 regencies/cities (Direktur Jenderal Penataan Agraria, 
2020) and 33 decrees of Customary Forest recognition in various provinces have also been successfully carried out (Nurbaya [ed.], 2018).

The existence of this overall legal umbrella is relatively sound in supporting the acceleration of the implementation of PTKH Inver at the district level because it involves many stakeholders, among them including KLHK, Ministry of Agriculture, and Ministry of Agrarian Affairs and Spatial Planning/National Land Agency (Ministry of ATR/BPN), the Forest Management Units (Kesatuan Pengelolaan Hutan, or KPH) and other stakeholders (Salim et al., 2018). However, the results have fallen sort of intended targets. Even the boundary setting initiatives have not yet reached the goal, much less the efforts to redistribute land to communities. As an additional note, approximately 2 years after it was announced, the PPTKH program only managed to complete 24 districts and there are still 135-145 districts whose state forest boundaries have yet to be resolved, amounting to an indicative land area of around 2 million hectares (Direktur Jenderal Penataan Agraria, 2020).

From this complex regulatory and institutional perspective, this study was conducted to illustrate the reality at the site level, particularly highlighting the different dynamics, challenges, and proposals to resolve community land tenure in state forests. Given the vast extent of land in state forests claimed by communities, therefore a better understanding is required to help resolve the security of assets and access. Indeed, existing studies related to agrarian reform in state forests are often much more focused on institutional aspects (e.g. Rachman, 2017; Luthfi, 2018), as well as a deeper examination of the policies and implementation of agrarian reform in state forests as summarized above (Sirait, 2017; Nugroho, 2017). There are also studies that describe the various challenges of implementing these complex reforms, particularly specific to Social Forestry policies and implementation (Muhsi, 2017; Siscawati et al., 2017; Supriyanto et al., 2017; Puspasari, 2017; Gunawan and Afriyanti, 2019). Nevertheless, there is much less analysis that goes into the implementation of critical reforms such as the PPTKH, especially governing the implementation of such policies at the site level. This study encourages researchers to take a closer look at these practical dimensions of such an influential provision governing access to local communities in state forests. In this paper, we specifically examine how the PPTKH provides an opportunity to realize the broader desires for land tenure access among local communities.

\section{Methods}

This study was conducted in Gedung Pekuon Village, Lengkiti Sub-district, Ogan Komering Ulu (OKU) Regency, South Sumatera. The selection of the research sites in OKU is due to the many settlements in this region included in state forests and targeted interest by the PPTKH program, especially in the Air Tebangka state forests. The sample was carried out based on the distribution of Indicative Maps of Land Objects of Agrarian Reform (Tanah Objek Reforma Agraria, or TORA - and specifically those identified in the $3^{\text {rd }}$ Edition) issued by the KLHK by Ministerial Decree LHK No. $8716 / 2018$. Although in the indicative map Gedung Pekuon is not included as a TORA site, however, based on the image interpretation in 2018, some of these villages are included in state forests, implicating both settlement areas and arable lands. In Presidential Regulation 88/2017, human settlements are the main target of boundary setting.

Gedung Pekuon was not included in the TORA Indicative Map because the mapping process was conducted at the ministerial level through a desk analysis method that overlays three maps (state forest designation map, boundary maps, state forest determination maps). These maps are also overlayed with image interpretation. The challenge was that when making such an indicative map, the identified land conditions were clustered but not homogeneous. The interpretation process therefore was prone to distortions, and it is foreseeably possible that there were villages not identified in the indicative mapping. This is a common oversight and likely occurred with respect in the case of Gedung Pekuon, even though the existing conditions had long been in the form of 
villages and settlement areas. Figure 1 shows how if the site is only seen from imagery interpretation by desk analysis method, then the Pekuon Village is thus difficult to identify as a village area.

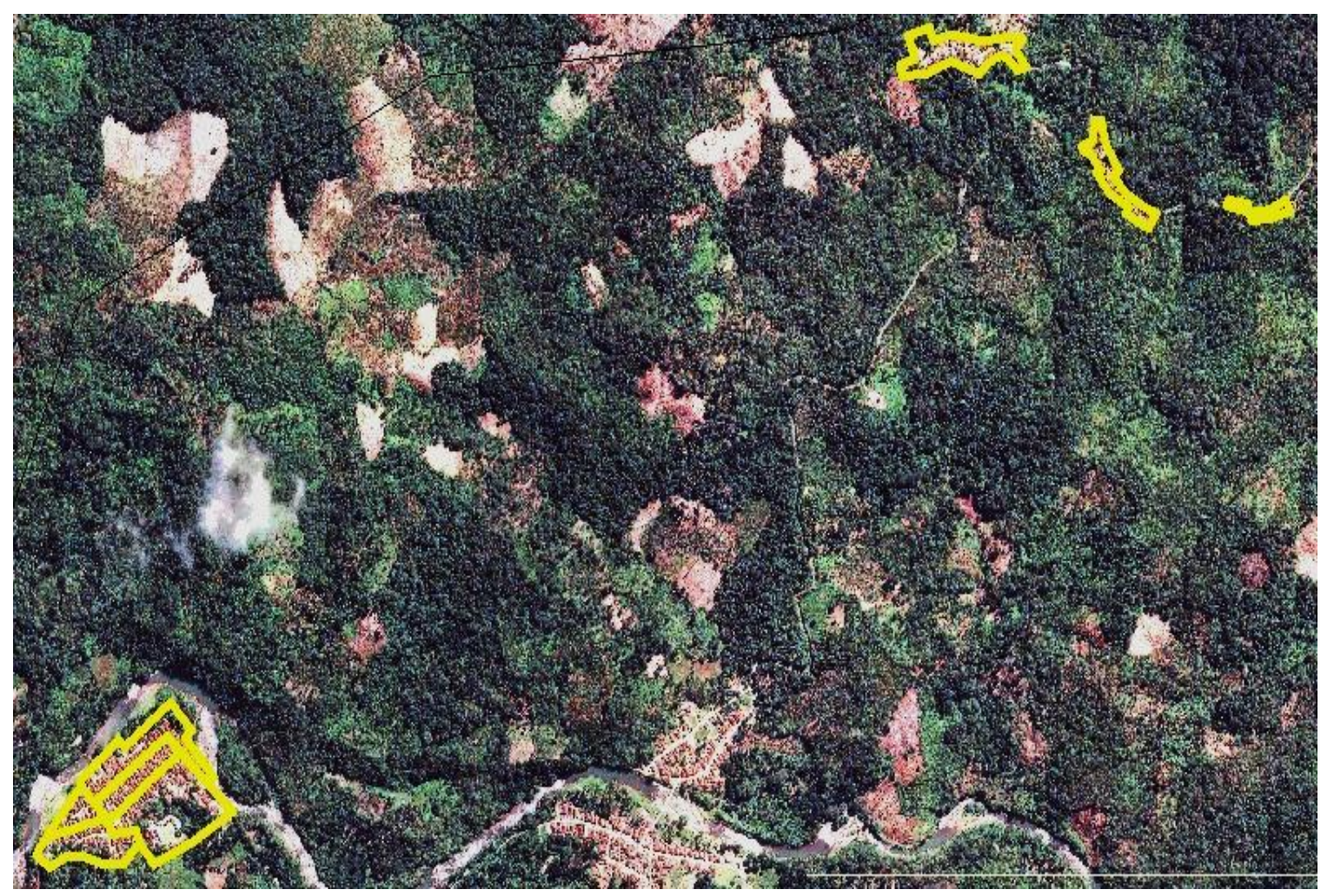

Figure 1. Likely Imagery Interpretation Oversight in the Settlement Area of Gedung Pekuon Village. Source: Orthogonal Upright Image of 2018 retrieved from the Geospatial Information Agency of the Ministry of ATR/BPN

Indicative maps will be more accurate if the data in the proposals are collected directly in coordination with each region and rely on the results of a ground check. In such a scenario each region would then forward the data to the district level under the control of the KPH who best understands the conditions of the state forests at the site level. The method can then help to minimize the distortion of the desk analysis interpretation results and reduce the problems that might arise from the unilateral determination of indicative maps without informing the public in advance.

When the authors observed one village in OKU in April 2019, including in Gedung Pekuon, the village institution and the community had not received any information regarding PPTKH program. With the help of the Head of the KPH of OKU and his section heads, the authors conducted intensive discussions to select a village to be sampled, and finally Gedung Pekuon Village was chosen as a representative case. Of the six hamlets found in Gedung Pekuon, Hamlet IV had the largest area included in Tebangka Water Production Forest. Therefore, the socialization of PTKH Inver was focused on Hamlet IV and involved a total of 71 households.

This study uses a participant observation strategy (Kawulich, 2005; Raco, 2010; Yunus, 2010). The authors conducted research at the location between April 9-25, 2019, and involved ourselves with the community, beginning with the process of identification, public outreach, and advocacy or assistance to help develop proposed PTKH Inver documents. Data collection was also carried out by interviewing village officials, the head of the hamlet (kepala dusun/ketua RW), head of the neighborhood (ketua RT), and community members. Informing the community of the program, conducting training on the method of proposing the inver, mentoring, working on the proposed 
program together, checking the community land boundaries in the field, making sketches, and completing all inver proposal documents were all part of the process. The community who becomes the subject of analysis are those that have lands in state forests, and they were directly involved from the beginning to the end. This strategy was used to explore data from the community, analyze and interpret in order to be more flexible (Creswell, 2010). The use of this strategy made it easier for the authors to identify and inventory community land in state forests and to help to find a solution to the model. The output is a collective PTKH Inver application document and the outcome is community capacity building. With this overall approach, the community also benefitted by obtaining the instruments to support in the realization of asset security and hopefully thereafter gain formal access to their lands.

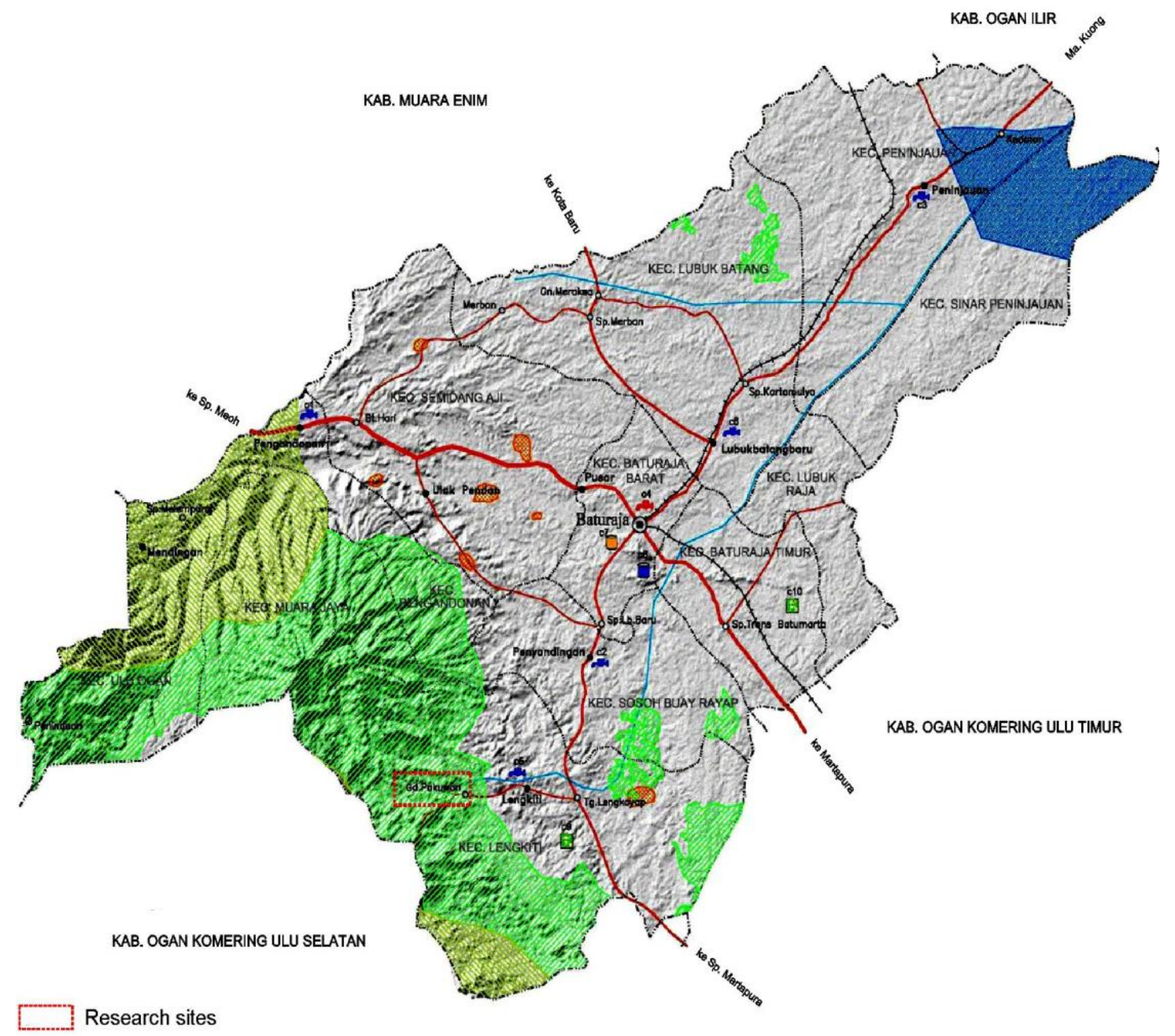

Figure 2. Research sites, Gedung Pekuon Village, Ogan Komering Ulu Regency.

\section{Results}

\subsection{Land tenure in state forests and the PPTKH mechanism}

There are at least two objectives of the PPTKH policy: first is land redistribution by establishing boundary setting; and second is development of a Social Forestry programs that have five corresponding schemes as outlined in Minister of LHK Regulation 83/2016 (Village forest, Community forest of HKM, Community-based timber plantations or HTR, customary forest or hutan 
adat, and partnership schemes). These programs are included as part of President Joko Widodo's strategy towards Agrarian Reform.

Agrarian reform originates from the overall initiative to release state forests from centralized control and was a scheme that had already been in place prior to Perpres 88/2017. This Perpres subsequently took the form of translating policy implementation in such a way that state forest released would be assigned status under the Other Land Allocations (APL) category. The designation does not involve KLHK, except in the upstream policy dimensions when land areas are planned for release. However, since Presidential Regulation 88/2017, the PPTKH program, now known as the policy for Agrarian Reform, is now carried out across sectors (KLHK, ATR/BPN, Regional Governments, and other stakeholders).

According to Utami, et al. (2018: 82-83), one of the most important issues in the implementation of PPTKH is the ineffectiveness of public outreach and engagement, resulting in limited information obtained by the community, especially on the document proposals that communities need to prepare (interviews with communities, KPH-OKU). This also resulted in the low achievement of target areas for agrarian reform when compared to the number of proposed collective PTKH Inver from communities. Whereas KLHK targeted the inventory of community land in state forests of around 2 million hectares, there are still around 145 regencies/cities among them that have not yet been listed (Direktur Jenderal Penataan Agraria, 2020).

The TORA release from state forests is obtained through the identification of state forest land as regulated in the Minister of LHK Regulation No. 17/2018, while its location refers to the Indicative Map of State forests Allocation for Provision of TORA Resources (3rd Edition). The mechanism for supplying TORA resources from the release of state forests is obtained through two models: by releasing state forests or by changing forest boundaries. According to Article 2 of Minister of LHK Regulation No. 17/2018, TORA sources originating from state forests consist of those listed in Table 1:

Table 1. Seven criteria of TORA in state forests

\begin{tabular}{|c|c|c|c|}
\hline No & TORA criteria for the release of state forests & Total (ha) & Settlement Policy \\
\hline 1 & $\begin{array}{l}\text { TORA allocation of } 20 \% \text { of state forests } \\
\text { release for plantations }\end{array}$ & 437,937 & Redistribution \\
\hline 2 & $\begin{array}{l}\text { Unproductive convertible production forest } \\
\text { (HPK) }\end{array}$ & $2,169,960$ & Redistribution \\
\hline 3 & $\begin{array}{l}\text { Government program for new rice field } \\
\text { reserves }\end{array}$ & 65,363 & $\begin{array}{l}\text { Sustainable Food } \\
\text { Agricultural } \\
\text { Land/LP2B }\end{array}$ \\
\hline 4 & $\begin{array}{l}\text { Transmigration settlements along with social } \\
\text { and public facility that have received principle } \\
\text { approval }\end{array}$ & 514,909 & $\begin{array}{l}\text { Resolved by legalizing } \\
\text { assets and Inver }\end{array}$ \\
\hline 5 & Settlements and social and public facility & 439,116 & $\begin{array}{l}\text { Resolved by legalizing } \\
\text { assets and Inver }\end{array}$ \\
\hline 6 & $\begin{array}{l}\text { Arable land in the form of rice fields and } \\
\text { ponds of a community }\end{array}$ & 379,227 & $\begin{array}{l}\text { Resolved by legalizing } \\
\text { assets and Inver }\end{array}$ \\
\hline 7 & $\begin{array}{l}\text { Dry land agriculture as main source of } \\
\text { livelihood for local community }\end{array}$ & 847,038 & $\begin{array}{l}\text { Resolved by legalizing } \\
\text { assets and Inver }\end{array}$ \\
\hline & Total & $4,853,550$ & \\
\hline
\end{tabular}

Source: Processed by the authors based on Minister of LHK Regulation No. 17/2018 and other sources 
Table 2. Pattern of Completion of TORA in State forests

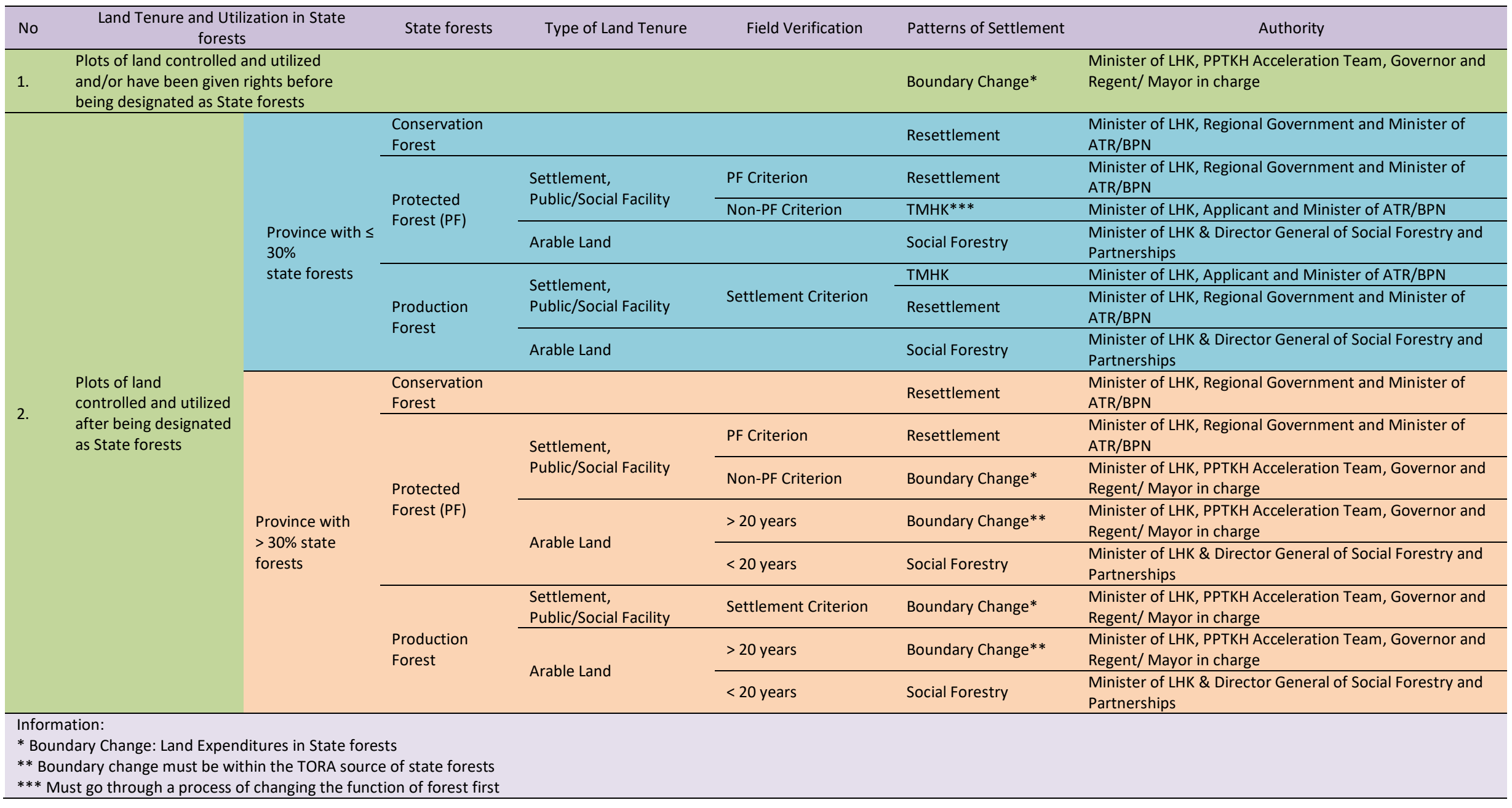

Source: Processed by the authors based on Presidential Regulation No. 88/2017 and Minister of LHK Regulation No. 17/2018. 
Of the seven criteria listed in Table 1 , only criterias 4 to 7 are settled by using the PPTKH scheme. The Minister of LHK established an additional policy for the two settlement models. The first covers the model for criteria number 1 to 3 , which is called the non-Inver scheme; as opposed to the criteria 4 to 7 which are the PTKH Inver settlement scheme. Criteria number 1 is a TORA that has been released from a state forest and its status has become non-forest land, while criteria 2 refers to the forest reserve mechanism for TORA as stipulated in Minister of LHK Regulation No.17/2018 Article 8 to 12. Criteria 3 applies the rules under Article 3 Paragraph 2, and criterial 4 to 7 are settled with the PTKH Inver scheme because they are related to land controlled by communities in state forests. Therefore, inventories and verification are also necessary and the approach is stipulated in Presidential Regulation No. 88/2017 and Minister of Economic Affairs Regulation No. 3/2018.

TORA recipients that originate from changes in state forest boundaries are individuals who have citizenship; agencies both from the central or regional government agency; registered social/religious legal entity in accordance with statutory provisions; or customary law community whose existence is determined by local regulations and has evidence of land tenure. PPTKH procedure is then carried out in stages, consisting of:

1. Inventory of land tenure in state forests;

2. Land tenure verification and recommendation for submission;

3. Determination of patterns of settlement of land tenure and utilization in state forests;

4. Issuance of decisions on the completion of control and use of land in state forests; and

5. Issuance of certificate of land rights.

These five stages are problematic, because it is not an easy to be handled by the Inver Team in the field, which in practice consumes a lot of time and goes through a long bureaucratic path. It starts with public engagement, which must originate from a proposal in the community, then proposed by the regent, followed by an issuance of a recommendation from the governor and ends with the decision of the Minister of LHK, who determines whether the settlement is conducted through changes in boundaries, exchange of state forests, Social Forestry or a resettlement program. The long process is in place because PPTKH begins from the bottom (a community proposal) and must travel through each level of bureaucracy all the way to the ministerial level (see Figure 10). The following table depicts land objects that are controlled by the community, types, settlement patterns and the parties who are authorized to work on them.

\subsection{Inventory of community land tenure in state forests in Ogan Kemoring Ulu Regency}

The control and use of land in state forests in OKU Regency in the form of settlements occurred in several state forests, one of which was in Tebangka Water Production Forest 1 . The location of Tebangka Water Production Forest was included in the administrative area of OKU Regency and the forest administration area is under the jurisdiction of the Technical Implementation Unit of the Forest Management Unit of Region VI (UPTD KPH Wilayah VI) Bukit Nanti-Martapura (Dinas Kehutanan Provinsi Sumatera Selatan, 2018, IV-151).

A note from the South Sumatra Provincial Forestry Service stated that land ownership took place within the Tebangka Water Production Forest, that is a village within the state forests was used as settlement and arable land. The villages within the state forests were Tihang, Negeri Agung, Lubuk Hara, Lepak Pandan, Sindang Negeri, Rantau Kumpay, Penantian, Tualang, Rantau Kumpay KPH Transmigration Village and Gedung Pekuon (Dinas Kehutanan Provinsi Sumatera Selatan 2018, IV-152). Gedung Pekuon is a village of 3,784 hectares located at an altitude of 159 masl (Badan Pusat Statistik Kabupaten Ogan Komering Ulu, 2018).

\footnotetext{
${ }^{1}$ Tebangka Water Production Forest is at $103^{\circ} 54^{\prime} 57.39^{\prime \prime}$ up to $104^{\circ} 04^{\prime} 22,749^{\prime \prime}$ East Longitude and $4^{\circ} 05^{\prime} 52,687^{\prime \prime}$ up to $4^{\circ} 18^{\prime} 11,081^{\prime \prime}$ South Latitude.
} 
Gedung Pekuon is not included in the TORA Allocation Indicative Map (3rd Edition) of South Sumatra, but the PTKH Inver policy provides support to villages that are not included in the Indicative Map to remain inverred, especially land for settlements (Interview with the Head of BPKH South Sumatra, April 2019). This consideration can be made with the recommendation of the regent who explains that the community are under regency jurisdication, and that the area is a village that has long existed and has been as a site for settlements. This determination is in accordance with Minister of Forestry Regulation Number P.62/Menhut-II/2013 which states that settlements within a state forest may be excluded from the forest if there are a minimum of ten houses in groups. This situation illustrates the need to conduct the PTKH Inver to resolve land tenure problems in Tebangka Water Production State forests conducted by the people of Gedung Pekuon Village.

At the beginning of 2019, the PTKH Inver activities carried out by the Forestry personnel, together with BPKH II and other stakeholders in OKU Regency were only at the stage of conducting an analysis using imagery to determine the location of the PTKH Inver. Until April 2019, the stage reached only the public outreach process at the district level, and an audience was held with the OKU Regent. During the first public outreach event with the Provincial Forestry personnel, BPKH had invited village heads, but there were several village heads who were not present. Furthermore, the authors promoted PTKH Inver in Gedung Pekuon with the aim of transferring information related to PTKH Inver to the community as well as assisting the community in preparing documents and completing application documents until they could be submitted to the PTKH Inver team.

The first stage of PTKH Inver public outreach was carried out for one week by dividing the villagers into groups. This took a long time to communicate because, firstly, the authors must visit and convince the village leaders. On the other hand, the work pattern of the authors followed the work rhythm of the villagers (mostly farmers) who only had time between $4 \mathrm{pm}$ and $9 \mathrm{pm}$. The public outreach was carried out through direct face-to-face and group discussion as well as demonstrating procedures for understanding the PPTKH workflow, introducing forms, completing documents and making sketches in a simple manner while explaining and working (learning by doing) by involving all villagers. Inver public outreach also used the PTKH Inver application forms that was in accordance with Minister of Economic Affairs Regulation No. 3/2018. The community were all invited to fill out together the PTKH Inver application forms. To complete the PTKH Inver application forms, the community as prospective PTKH Inver applicants were taught how to identify the location of lands, estimate the areas of lands used as houses and yards and identify the history of land acquisition. The authors also invited the villagers to go to the field to directly see the position of their lands and make sketches of the sites.

The output of the first stage of the outreach activity was in the form of application documents for PTKH Inver from individuals and public facilities (a school and a mosque). The documents were completed gradually in the first week in the field. The documents produced by the applicants consisted of: 1) Identity Card of the prospective applicants; 2) prospective applicants' family cards; 3) PTKH Inver application forms for individuals; 4) land sketch forms for individuals; and 5) Physical Land Parcel Ownership Statement (Surat Pernyataan Penguasaan Fisik Bidang Tanah) or SP2FBT. Figure 3 is an example of the work undertaken for the PTKH Inver application form for individuals produced by a villager who claimed an area of land. 


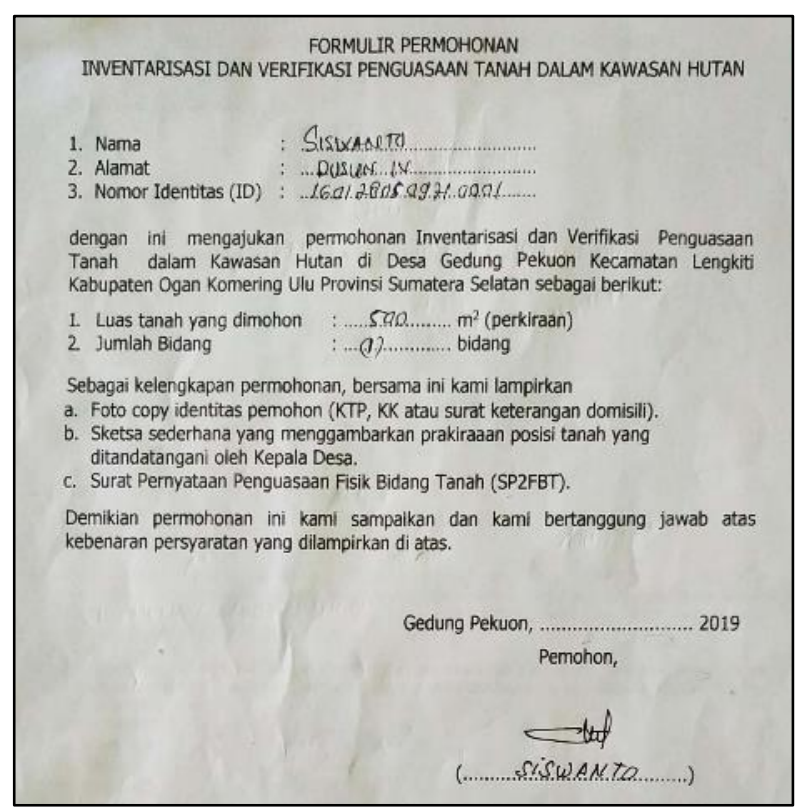

Figure 3. Example of a PTKH Inver Application Form for Individuals. Source: Document of the authors and the community's works for Gedung Pekuon Village PTKH Inver Application 2019

The applicants' Identity Cards and Family Cards of the prospective applicants did not need to be presented by the authors. Below is an example of a land sketch for individuals (Figure 2), which was also the work of the community and presented as a picture of the SP2FBT as stipulated in Minister of Economic Affairs Regulation No. 3/2018.

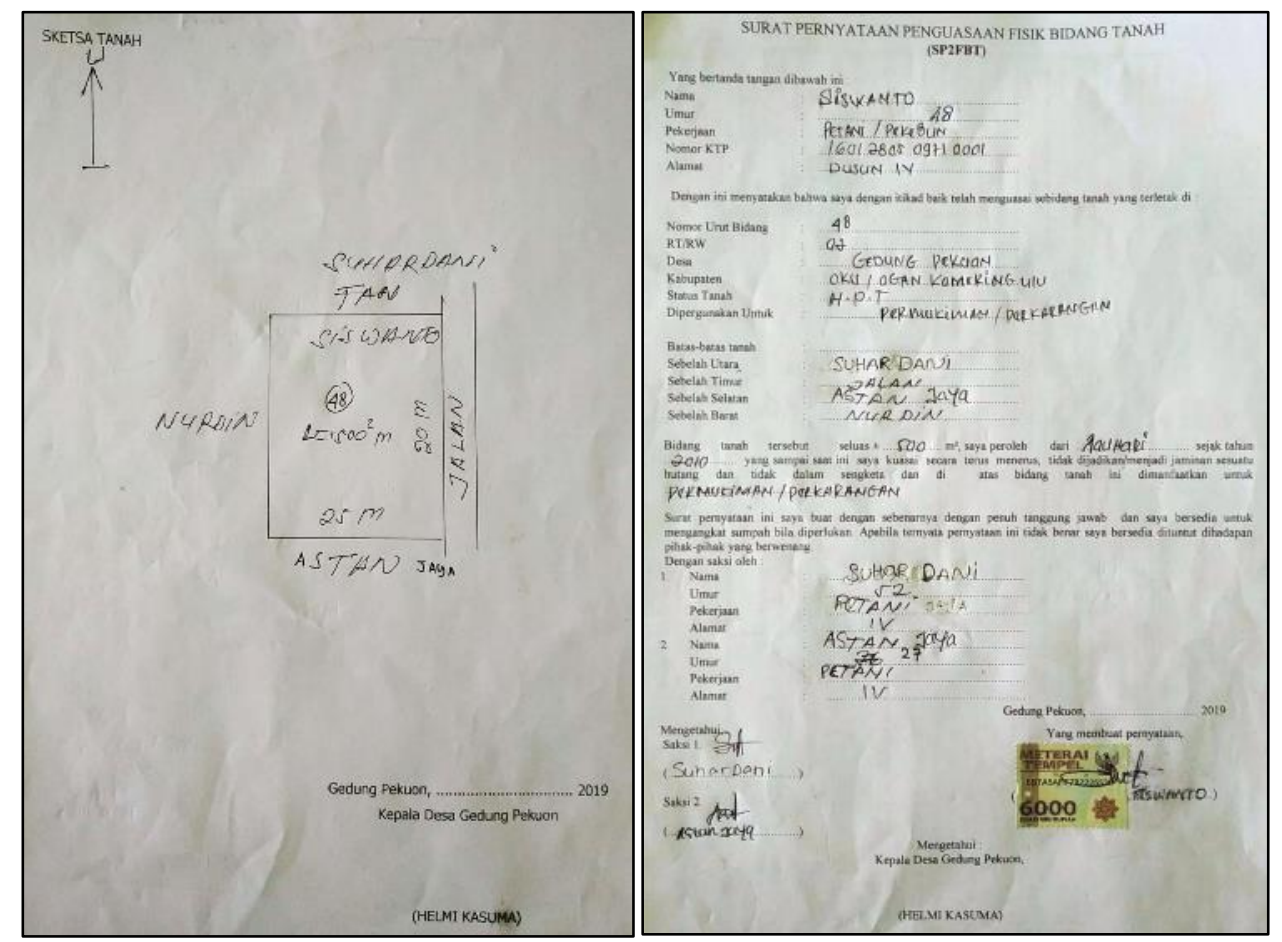

Figure 4 \& 5. Examples of land sketches for individuals (left) and physical land parcel ownership statement (SP2FBT) (right). Source: Document of the authors and the community's works for Gedung Pekuon Village PTKH Inver Application 2019 
The documents produced by the applicants were then submitted collectively and then signed by the village head. PTKH Inver application forms for individuals, land sketches and SP2FBT that had been signed by the applicants and the village head were collected for recapitulation of the applicant list by using a list of types of land use and history of land tenure. Ideally, recapitulation of the list of applicants should have been done by the village head and staffs, but due to some limitations, the hamlet head recapitulated the list of applicants manually by collecting all of the applications. The head of the neighborhood ward, as the respondent of the smallest jurisdictional area, then verified the data in the application forms to ensure that what was written in the application forms were in accordance with the provisions and facts in the field. Thereafter, the authors assisted the recapitulation of the list of applicants. The recapitulation of the applicant list is shown in Table 2.

Table 2. Example of the recapitulation of applicant list in Gedung Pekuon Village

\begin{tabular}{|c|c|c|c|c|c|}
\hline No & $\begin{array}{c}\text { Land } \\
\text { Parcel } \\
\text { Serial } \\
\text { Number }\end{array}$ & $\begin{array}{c}\text { Type of Land } \\
\text { Use }\end{array}$ & History of Land Tenure & $\begin{array}{c}\text { Name of the } \\
\text { Subject }\end{array}$ & $\begin{array}{c}\text { Information } \\
\text { (Area, Proof of } \\
\text { Land Tenure, etc.) }\end{array}$ \\
\hline 1 & 26 & $\begin{array}{l}\text { House and } \\
\text { Yard }\end{array}$ & $\begin{array}{l}\text { Retrieved from Mr. } \\
\text { Sadiman in } 2018\end{array}$ & Sudarman & 150 \\
\hline 2 & 25 & $\begin{array}{l}\text { House and } \\
\text { Yard }\end{array}$ & $\begin{array}{l}\text { Retrieved from Mr. Rudi in } \\
2011\end{array}$ & Jauhari & 150 \\
\hline 3 & 20 & $\begin{array}{l}\text { House and } \\
\text { Yard }\end{array}$ & $\begin{array}{l}\text { Retrieved from Mr. } \\
\text { Sukardi in } 2003\end{array}$ & Wagimin & 150 \\
\hline 4 & 21 & $\begin{array}{l}\text { House and } \\
\text { Yard }\end{array}$ & $\begin{array}{l}\text { Retrieved from Mr. Subihis } \\
\text { in } 1998\end{array}$ & Kalimantan & 150 \\
\hline 5 & 3 & $\begin{array}{l}\text { House and } \\
\text { Yard }\end{array}$ & $\begin{array}{l}\text { Retrieved from Mr. Usman } \\
\text { in } 2009\end{array}$ & Saniyo & 150 \\
\hline 6 & 13 & $\begin{array}{l}\text { House and } \\
\text { Yard }\end{array}$ & $\begin{array}{l}\text { Retrieved from Mr. M. } \\
\text { Subir in } 1980\end{array}$ & Subirin & 300 \\
\hline 7 & 16 & $\begin{array}{l}\text { House and } \\
\text { Yard }\end{array}$ & $\begin{array}{l}\text { Retrieved from Mr. Des } \\
\text { Yulius in } 2001\end{array}$ & Purwanti & 150 \\
\hline 8 & 10 & $\begin{array}{l}\text { House and } \\
\text { Yard }\end{array}$ & $\begin{array}{l}\text { Retrieved from Mr. Albadri } \\
\text { in } 1997\end{array}$ & Lucky & 150 \\
\hline 9 & 52 & $\begin{array}{l}\text { House and } \\
\text { Yard }\end{array}$ & $\begin{array}{l}\text { Retrieved from Mr. Reza } \\
\text { Pahlepi in } 2007\end{array}$ & Junainah & 80 \\
\hline 10 & 53 & $\begin{array}{l}\text { House and } \\
\text { Yard }\end{array}$ & $\begin{array}{l}\text { Retrieved from Mr. Zulfikri } \\
\text { in } 2006\end{array}$ & $\begin{array}{l}\text { Reza } \\
\text { Pahlepi }\end{array}$ & 122 \\
\hline 11 & 48 & $\begin{array}{l}\text { House and } \\
\text { Yard }\end{array}$ & $\begin{array}{l}\text { Retrieved from Mr. Jauhari } \\
\text { in } 2010\end{array}$ & Siswanto & 500 \\
\hline 12 & 28 & $\begin{array}{l}\text { House and } \\
\text { Yard }\end{array}$ & $\begin{array}{l}\text { Retrieved from Mr. Yakup } \\
\text { in } 1999\end{array}$ & Firdaus & 200 \\
\hline 13 & 36 & $\begin{array}{l}\text { House and } \\
\text { Yard }\end{array}$ & $\begin{array}{l}\text { Retrieved from Mr. Umar } \\
\text { Zuki in } 2000\end{array}$ & Ardiyansah & 1.000 \\
\hline 14 & 30 & $\begin{array}{l}\text { House and } \\
\text { Yard }\end{array}$ & $\begin{array}{l}\text { Retrieved from Mrs. } \\
\text { Masriyah in } 1980\end{array}$ & Surimas & 500 \\
\hline 15 & 47 & $\begin{array}{l}\text { House and } \\
\text { Yard }\end{array}$ & $\begin{array}{l}\text { Retrieved from Mr. Nurdin } \\
\text { in } 2017\end{array}$ & Astan Jaya & 120 \\
\hline$\ldots$ & $\ldots$ & $\ldots$ & and so on ... & $\ldots$ & $\ldots$ \\
\hline
\end{tabular}

Source: Document of the authors and the community's works for Gedung Pekuon Village PTKH Inver Application 2019

When conducting outreach with the community, there were 71 households in Gedung Pekuon, and 19 proposals could not be processed because the land statuses were unclear as to who owned 
them. This means that the families had not agreed upon whose names the lands would be registered. In most cases, the lands were inherited lands that had not been divided, so the process could not be continued until the status of ownership (names of the owners) were agreed upon.

Based on the recapitulation of the list of applicants, the community was enthusiastic in following the process of the public outreach on PTKH Inver. As many as $96 \%$ of the community participated in the outreach and $72 \%$ of them were able to submit an application for PTKH Inver. After recapitulating the applicant list, the village head then made the PTKH Inver application forms from individuals (Form 1a) into a collective PTKH Inver application.

After the PTKH Inver application forms for individuals were completed, land sketches for individuals and SP2FBT were signed by the applicants and the village head. The village head then made a collective PTKH Inver application with individual applicants. The collective PTKH Inver application document with individual applicants consisted of:

1. Identity Card of the Village Head of Gedung Pekuon Village;

2. PTKH Inver Application Forms from individuals (Application Form 1a);

3. Land collective sketch form that describes the positions/details of each applicant's land parcel (Application Form 2);

4. List of Application Recapitulation (Application Form 3); and

5. SP2FBT of all parcels submitted as an application for PTKH Inver.

The PTKH Inver Application Forms from the individuals (Application Form 1a) is shown in Figure 6 below.

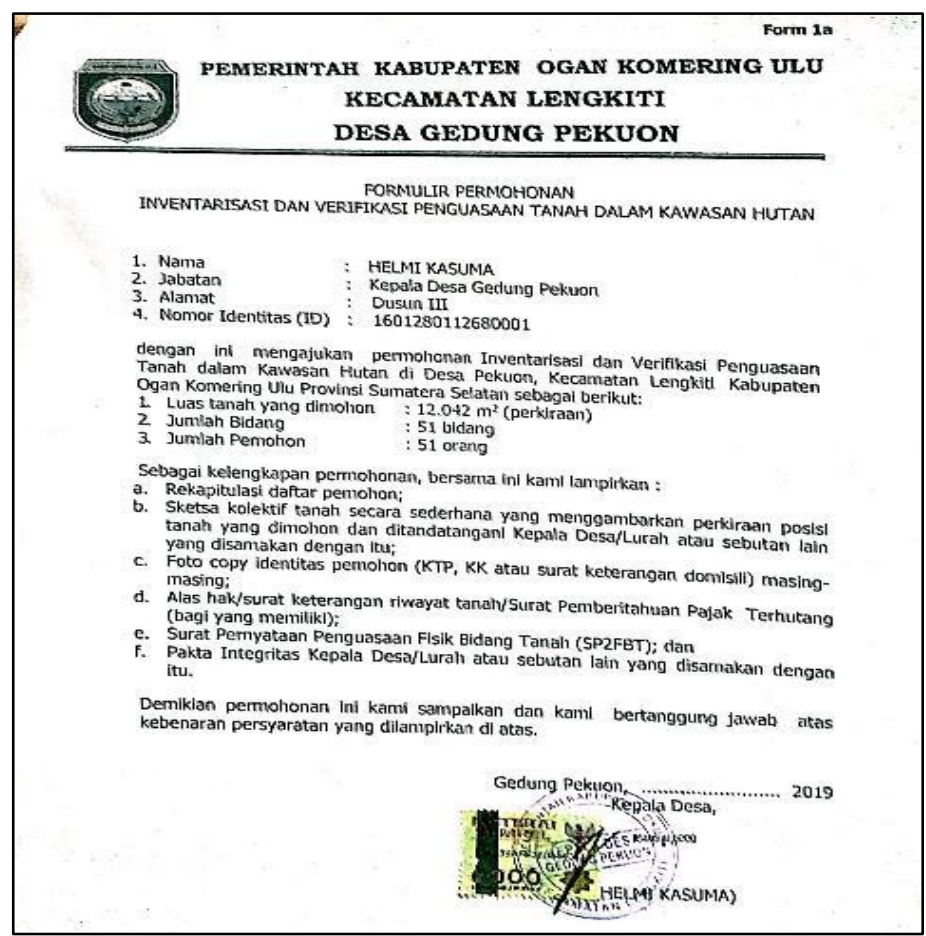

Figure 6. Application Form 1a. Source: Document of Gedung Pekuon Village PTKH Inver Application 2019

The next step was to make a collective sketch. The collective sketch was done by the village head and assisted by the authors, while the village staff collected individual sketches to the head of the neighborhood and showed the boundaries to be drawn and made into electronic files. A simple collective sketch on paper by hand was done by the village head and his staff. 
Application Form 2 was originally made for the entire field to be submitted as a PTKH Inver application, consisting of 51 plots of land in the form of settlement areas and 2 plots of land in the form of a public facility, which are an elementary school and a mosque. The whole plot of land was plotted on a piece of paper (preferably on A3 paper to get a bigger space, but if there is no A3 paper, it can be drawn on A4 papers separately so the land parcel serial numbers can be read easily).

In the case of Gedung Pekuon, each plot of the land to be submitted as a PTKH Inver application was not located close to each other, and if the entire plots were placed onto an A4 paper, the sketch would look too small and difficult to identify. For this reason, Application Form 2 was made separately according to field conditions. Because of the limited space, this paper only displays a sketch (Figure 7) on one sheet signed by the village head for all parcels of land to be submitted as a PTKH Inver application.

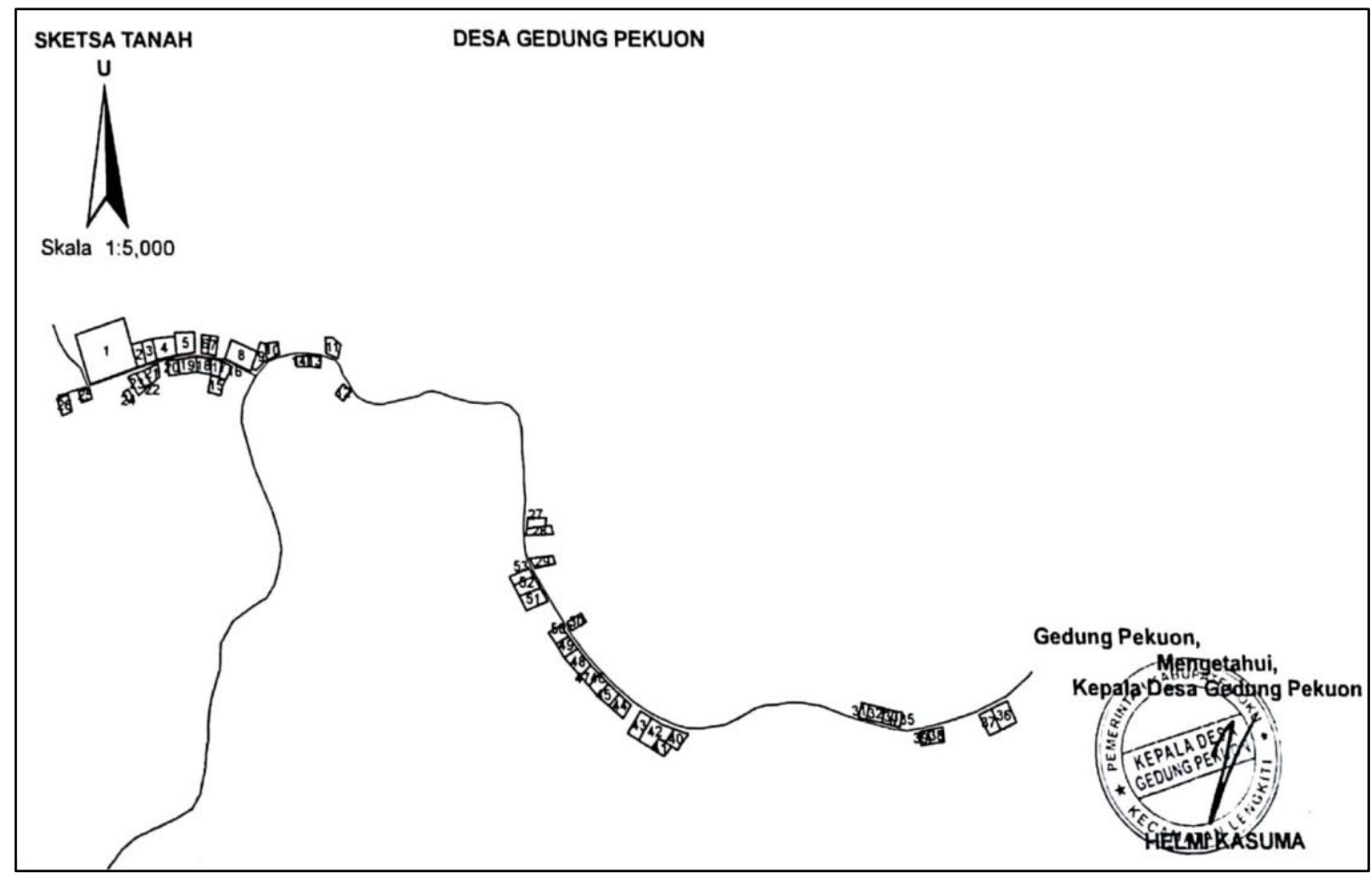

Figure 7. Application Form 2 of Neighborhood 1 and 2 (Communal Proposal Combined in One Collective Sketch by the Village Head). Source: Document of Gedung Pekuon Village PTKH Inver Application 2019

In addition to individual applications listed above, there were also applications for public facilities, which included an elementary school and a mosque. The proposing procedure is no different from the individual PTKH Inver application, except for the status of the subject (the applicant) as is explained in Minister of Economic Affairs Regulation No. 3/2018 in which applicants for public and social facilities are central/regional government agencies and social/religious legal entities. If both were unavailable, the application could be completed by using a village head's name. In the case of Gedung Pekuon, the application was submitted on behalf of the village head. The PTKH Inver application document for public facility consisted of:

1. Identity Card of the Village Head of Gedung Pekuon;

2. PTKH Inver Application Form from religious/social legal entities (Application Form 1b);

3. Collective land sketch application form that describes the positions/details of land parcels of the public facilities (Application Form 2); and

4. SP2FBT of the land parcels proposed as public facilities (Application Form 4). 
In addition to the elementary school, a mosque was also listed for application. The SP2FBT was issued by the religious/social legal entity alongside its corresponding land sketches. After SP2FBT and the sketches were completed, Application Form $1 \mathrm{~b}$ was made for both of them as an application for a collective PTKH Inver in accordance with the Annex to Minister of Economic Affairs Regulation No. 3/2018. Application Form $1 \mathrm{~b}$ was signed by the village head and is shown in Figure 8.

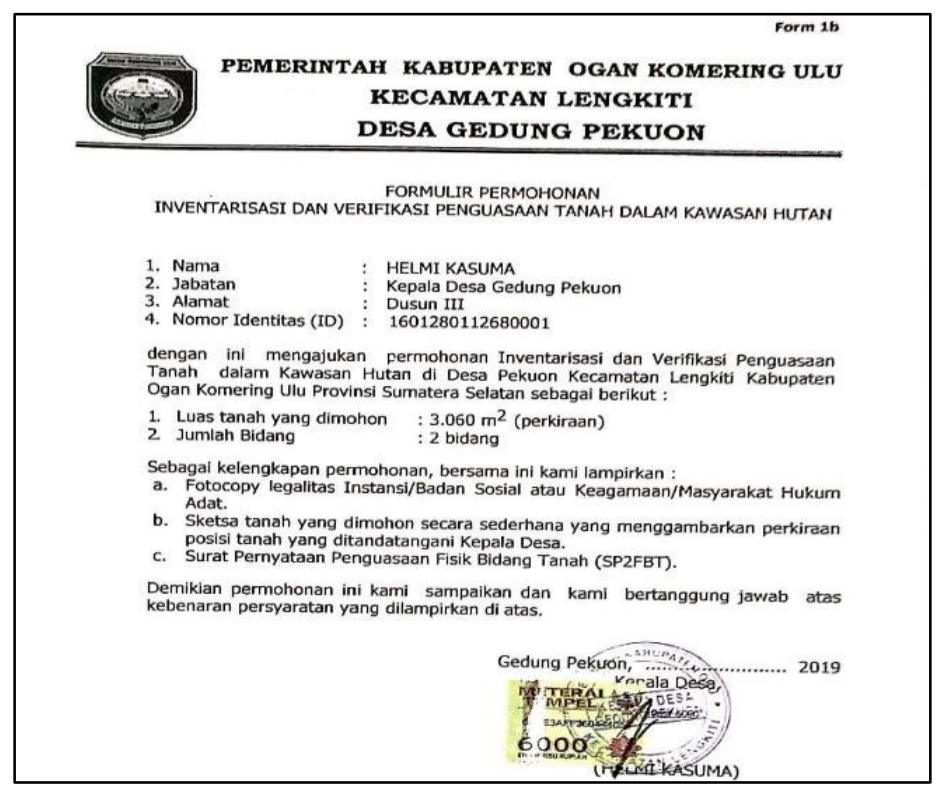

Figure 8. Application Form 1b. Source: Document of Gedung Pekuon Village PTKH Inver Application 2019

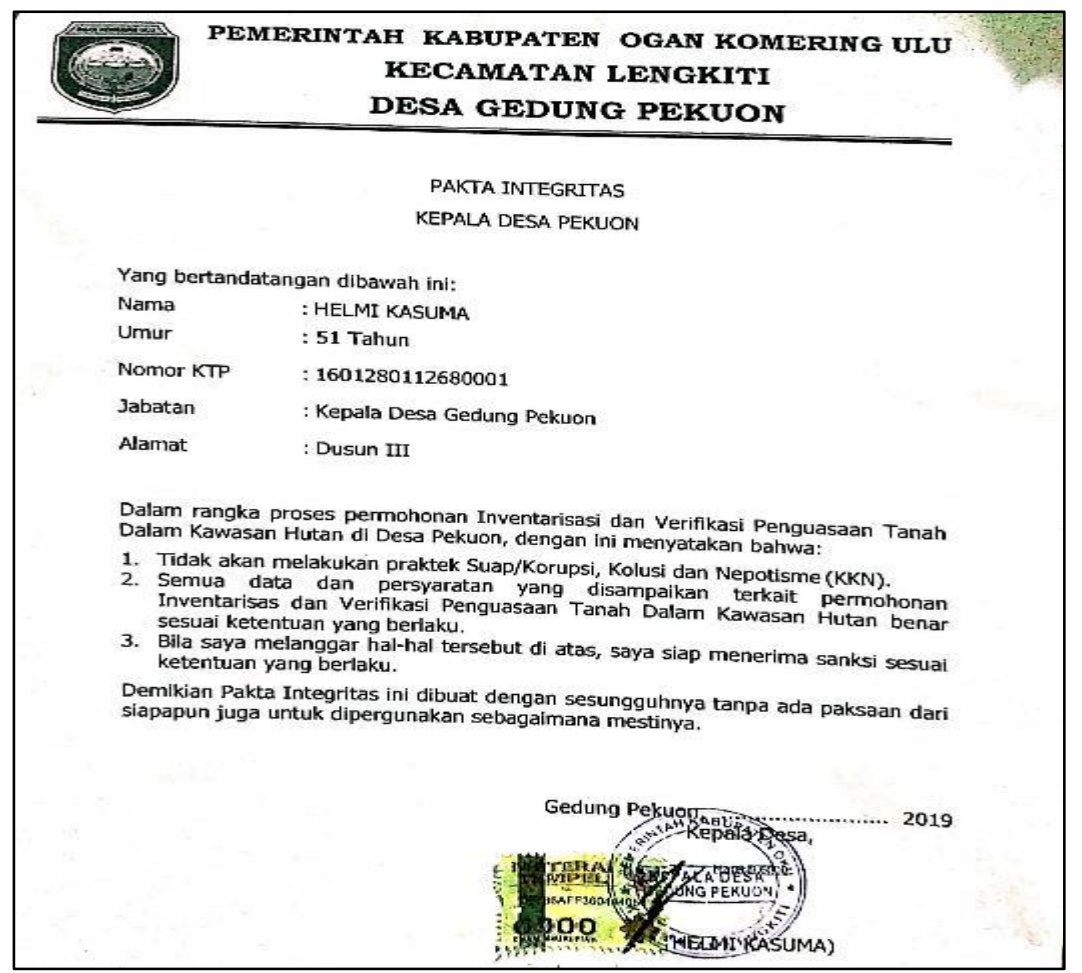

Figure 9. Integrity Pact. Source: Document of Gedung Pekuon Village PTKH Inver Application 2019 
The final step taken in the process of assisting the PTKH Inver applications for both individuals and public facility was thus completed. This was then followed up by the village head making an integrity pact. The integrity pact can be seen in Figure 9.

The final stage in completing the collective PTKH Inver application documents was a field check by observing the suitability of the documents with the referred lands. This stage was carried out by the researchers, prospective applicants, Head of Neighborhood 1, Head of Neighborhood 2, and Head of Hamlet IV. By doing a field check, it could then be ensured that the subjects and objects of the PTKH Inver application documents were in accordance with one another. The implementation of this stage must involve the parties so that mistakes or overlaps between the subjects and objects do not occur.

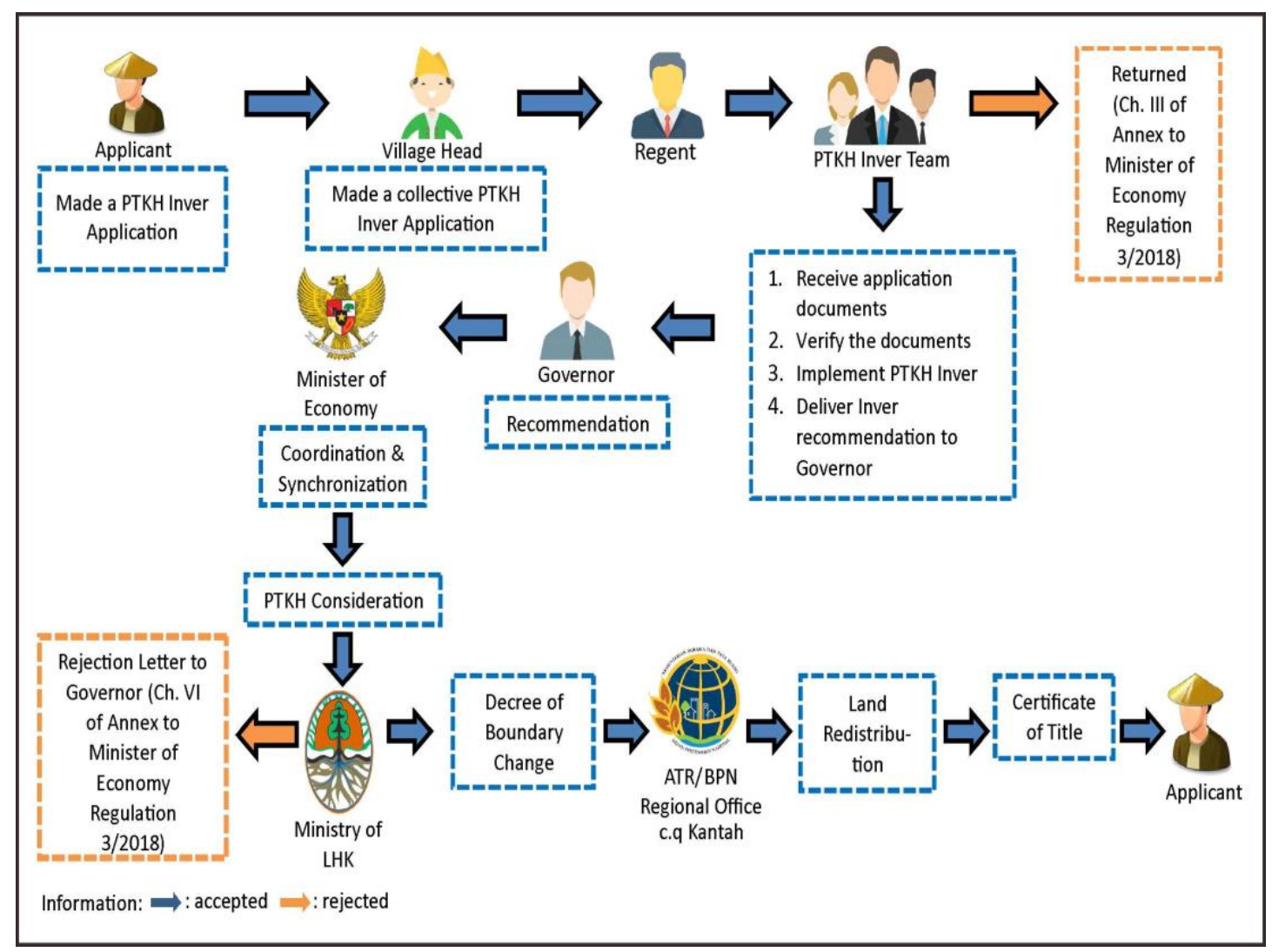

Figure 10. Changes to boundary setting implementation procedure in Hamlet IV Gedung Pekuon Village. Source: Processed by the authors based on Minister of Economy Regulation No. 3 of 2018

The process of making the collective PTKH Inver application for Gedung Pekuon Village was completed with the signing of the Integrity Pact and a field check. The next step would be followed up in accordance with Minister of Economic Affairs Regulation No. 3/2018. In this stage the Head of Gedung Pekuon Village submitted the collective PTKH Inver request to OKU Regent with information from the Head of the Lengkiti Sub-district. The OKU Regent would then submit the collective PTKH Inver request with other villages that proposed to the PTKH Inver Team (South Sumatra Provincial Forestry Service c.q. BPKH Region II). After receiving a request from the OKU Regent, the PTKH Inver Team would review the intended applications and discuss the timetable for the implementation of the PTKH Inver. If the application documents had been declared as complete by the Inver Team, it would be followed up with the implementation of the PTKH Inver in the villages. A recommendation meeting at the provincial level and its results would then be followed by the submission of a 
recommendation to the Governor of South Sumatra and forwarded to the Coordinating Minister for Economic Affairs as the Head of PPTKH Acceleration Team with a copy sent to the Minister of LHK. The final result of the Acceleration Team's decision was at least two, rejected or accepted, with two models: boundary setting (removed from the state forest) or included in the Social Forestry scheme. This study only looks at one process of change, which is the boundary setting, because the proposed community land is only at the level of house and yard. The complete process can be seen in the following flow in Figure 10.

\section{Discussion}

\subsection{Community Land Settlement Issue in state forests}

Land tenure in state forests is a dilemma because state forests in Indonesia contain complex economic, ecological, social, cultural and political dimensions. Many villages are drawn within the boundaries of state forests, which include land that is controlled and used by a community as their settlement areas, public/social facilities, arable land, and managed in complex systems of customary law that have been in place for generations. Unclear land status commonly found in state forests is therefore unsurprisingly a source of conflict. This is particularly true when state authorities seek to exercise their control over an aera also claimed by communities, sometimes with forced removal or denial to resource access (Kane et al., 2018). The national record from the Consortium for Agrarian Reform (Konsorsium Pembaruan Agraria, or KPA) has catalogued the numerous conflicts taking place in the forest sector, which account for numbers that remain high (KPA, 2018).

As the source of conflict are due to overlapping land claims, the PPTKH scheme promoted by Presidential Regulation No. 88/2017 and Minister of Economic Affairs Regulation No. 3/2018 offers a solution to the problem through the PTKH Inver mechanism, which is undertaken by removing land parcels from state forests by redrawing boundaries of state forests, exchanging state forest areas, social forestry programs, and resettlement. The PTKH Inver is carried out across sectors by a PTKH Inver Team, thus opening opportunities for integration between sectors from the central to the regional level. Lutfi (2018) in his study put forward the argument that the division of authority in the PTKH Inver Team requires a synergy between sectors because one of the conditions for successful implementation of Agrarian Reform is political will of the ruling elite in integrating across sectors/ministries. Observations made by Sutaryono (2018) also reinforces this argument that collaboration across sectors is needed in accordance with their authority in the implementation of the PTKH Inver.

In practice, there are many problems in the implementation of the PTKH Inver. Utami et al. (2018) explained that there are still different perceptions about the TORA relative to the state forest land, both at the community level and between stakeholders. Some villagers perceive that controlling land in a state forest without inventory and verification process is not a problem, because they cleared the forest and then managed it. On the other hand, some of the ATR/BPN Ministrial officials consider PPTKH to be the Ministry of LHK's duty and not ATR/BPN's, even though Presidential Regulation No. 88/2017 binds the two sectors together, further mandating local governments to work together to solve overlapping claims. In addition, the lack of budget availability and ineffective public outreach leads to a limited number of proposals for PTKH Inver by the community ever getting approved, so results thus far area still far from their intended target. As of the end of 2019, TORA lands have not been successfully distributed to the people who have proposed claims because those successful have only obtained the level Decree on Boundary Change from KLHK. There is still one more process that must be completed, which is the measurement of fields and redistribution, because the main objective of the PTKH Inver is the redistribution of land to the community.

The authors suggest that researchers conduct collaborative action research in a way that involves academics/researchers with communities and bureaucrats, directly getting involved in 
increasing community capacity building by learning together in the field so that they can be empowered to continue to learn about effective measures (Moeliono et al., 2017).

\subsection{Oku Regency: TORA in state forests and the PTKH Inver}

The PTKH Inver Team carried out an inventory and verification of land plots that were most likely to be excluded from state forests through a boundary change scheme; as long as it is still within the scope of one regency it will not be limited by government administrative boundaries. The PTKH Inver in OKU Regency is planned by the BPKH and is based on the 2018 indicative map divided into three PTKH Inver criteria: arable land in the form of rice fields and people's ponds, dryland agriculture which is the main source of livelihood of the local community, as well as settlements and public and social facilities. The target of the PTKH Inver with the criteria for settlements and public and social facility covers an area of \pm 476.06 hectares and is targeted to be excluded from state forests through changes in boundaries.

The implementation of PTKH Inver in OKU Regency in early 2019 was still at the stage of hearing with the Regent of OKU at the submission of this article, so the collective PTKH Inver application of Gedung Pekuon Village could not be proposed yet, because officially the South Sumatra Forestry Agency and BPKH II had not yet conducted an Inver at OKU. The authors cooperated with BPKH II, $\mathrm{KPH}$ and the community by taking the initiative to prepare the documents needed by the Inver Team and accompanied the community in following the regulations to prepare the documents. The PTKH Inver application document that resulted from the assistance by the authors was eventually proposed after the Inver Team officially went to the field. The work that we did aimed to empower the people of Gedung Pekuon Village so that they have the knowledge to propose land claims. The capacity developed through this process will be able to help them independently propose lands to the PTKH Inver Team for lands outside of which they had been working together. Because the samples that the authors took were only limited to houses and yards, the community land for cultivation had not yet been proposed and now the community has the understanding and the means to prepare such documentation. It is hoped that what the authors did together will become new knowledge for the community to propose for these other lands when the Inver Team goes to OKU in the future.

Field observations showed that Hamlet IV of Gedung Pekuon Village has become a settlement and public facility. The public facility that has been built is a Subsidiary Elementary School which is a branch of OKU 79 Elementary School, the construction of which was carried out in 2009 and financed by the government. This fact shows that the existence of Gedung Pekuon as a village has been recognized even though some of its territory is included in state forests.

Article 7 and 8 of Presidential Regulation No. 88 of 2017 emphasizes that the pattern of settlement of community land in state forests is carried out through four processes: by removing land parcels in state forests through changes in state forest boundaries, exchange of state forest lands, social forestry, and resettlement. The pattern of settlement is not necessarily open to as wide an interpretation as possible, and provides limits to avoid further degradation of the forest ecosystem. These limits are included as part of Article 21 of Presidential Regulation No. 88 of 2017 whereby one regency/city can only conduct the process once and is limited by a certain timeframe. This article is quite problematic because in practice, the PTKH Inver Acceleration Team is unable to conduct adequate public outreach, and it was proven that the Inver 2018 excluded many villages that did not propose their land claims because of limited information. By referring to the article above, it means that villages that do not propose a claim will no longer have the opportunity to do so in subsequent years.

The people of Gedung Pekuon Village understand the importance of recognizing the rights to their land claims. Some residents admitted that they had intended to sell their land to people in other sub-districts, but none of them were willing to buy it because they knew that the area was 
included within state forest boundaries so that it was impossible to certify and appraise the land, furthering reducing the potential value of the land if resold. Unsurprisingly, the OKU Land Office did not dare to issue land certificates in state forests because this action would change the status of the state forests to non-state forests. The authority to change the status of the forest is under KLHK authority. Issuance of Certificate of Title in state forests will violate Article 4 paragraph (2) letter b of Law No. 41/1999 concerning Forestry.

The public outreach of PTKH Inver and the joint work that the authors conducted in Gedung Pekuon Village aimed to transfer information related to PTKH Inver to the community, as well as accompanying the community to complete the application documents so that it could be submitted to the Provincial PTKH Inver Team. What the authors prepared with citizens was in accordance with Minister of Economic Affairs Regulation No. 3/2018, so when the Inver Team from the South Sumatra Forestry Agency went to the field, the residents of Gedung Pekuon Village were ready to submit their proposal, because all the documents had been completed.

As far as the authors experienced in the field, the citizen participation both by the village head and community leaders were quite helpful in the process of identifying and communicating the PTKH Inver process. Village leaders provided guidance to the community in order to carry out the PTKH Inver application activities accordingly. Problems in the field arose, and the main obstacle that the authors experienced was the literacy level of the villagers. Likewise, villagers generally did not understand how the bureaucracy works and did not understand either how to get access to information, particularly aspects related to the PTKH Inver. As Firdaus, a village leader of Gedung Pekuon exprerssed to us: "We as ordinary people need the elders who can tell us" (Interview 19 April 2019).

This condition confirms the initial assumption of the authors that, in fact, the community really needs a clear status of assets and access to their land, especially to land that they have controlled for generations. Herein lies the importance of mentoring and joint work between stakeholders (across sectors) to make it happen. Only delegating responsibility for proposing PTKH Inver application to the community (bottom-up) without transfer of information and assistance (Pokharel et al., 2015; Mulyadi, 2013) will not necessarily help to achieve the overall intent of the targets set by KLHK and ATR/BPN. The experience from Gedung Pekuon Village highlighted that after assistance, the community is able to propose for other lands besides settlement areas. That is, the authors believe, if given the adequate and precise information, the community will quickly learn. In essence, local community participation (empowerment) is very important to improving communitybased development (Pokharel et al., 2015; Pujo et al., 2018). It is important to understand the different characteristics of the community in terms of cultural, geographic, social, political and demographic aspects because community capacity building carried out in one community may not necessarily be the same in another.

The PPTKH aims to resolve land tenure problems in state forests through redistribution of assets (ownership rights), support for asset development (Social Forestry) and legalization of assets. These aspects are all overseen by the authority of the Ministry of ATR/BPN, KLHK and Regional Governments. For this reason, cooperation of these institutions and other sectors is a prerequisite for the realization of supporting communities make claims to land in state forests. Related to this, based on the data obtained by the authors in the field, specifically with regards to residential land, this should be excluded from state forests (boundary change), while resident land that was included in state forests and serves as a source of livelihoods should be settled through a social forestry scheme. This is to provide guaranteed access to citizens who have long controlled the land.

\section{Conclusion}

The PPTKH program is an effort to accelerate the completion of land tenure in state forests in support of community claims. The PPTKH is critical because there continue to be many people who 
control land in state forests, which they have held legitimate claims to at times for many generations. The government is aware of this challenge and has developed mechanisms to settle claims. Even though a site may be recognized as a village but the physical village may still be located in a state forest. Infrastructure development by the government carried out in villages in state forests is an indication that the local government recognizes its existence, but on the other hand, also seems to "neglect" the situation.

More serious encouragement from various parties is needed because the PPTKH program has opened opportunities for the community to improve their access and formalize their assets. Data in the field shows that not many people were aware of the PPTKH program, so people could not identify the objects they have controlled in state forests. Knowledge transfer is needed to the community related to the implementation of PTKH Inver; one of the ways is action research. The participant observation strategy with fieldwork model will jointly encourage the community to independently identify, then submit an application for PTKH Inver through the PTKH Inver Team until finally the community's land rights are guaranteed, both supporting property rights and helping to better target other schemes such as social forestry. In other words, such efforts provide communities to establish legal certainty over their assets, helping to avoid tenure conflicts in the future.

\section{Acknowledgement}

The authors would like to thank the Center for Research and Community Service at the Yogyakarta National Land Academy (PPPM-STPN Yogyakarta) for providing access and assisting in conducting research. The authors would like to thank Westi Utami and Fitria Nurfaizah Ekawati who helped in the field. The authors also expresses his gratitude to those who helped, Mr. Manivast Zubayir, Mr. Taufik, Mr. Imam and Ms. Sintia from BPKH Region II; Mr. Muzawir in the South Sumatra Provincial Forestry Agency; Mrs. Siti Lela Sari, Mr. Arif and Mr. Hartono at the UPTD KPH Region VI Bukit Nanti-Martapura who accompanied during field work; as well as the Head of Gedung Pekuon Village and the people of Hamlet IV Gedung Pekuon Village who were actively involved throughout fieldwork.

\section{Conflicts of Interest}

The authors declare there is no risk of conflict of interest.

\section{References}

Badan Pusat Statistik (2014). Statistik potensi desa Indonesia (village potential statistics of Indonesia) 2014, Badan Pusat Statistik, Jakarta.

Badan Pusat Statistik Kabupaten Ogan Komering Ulu. (2018). Kecamatan Lengkiti dalam Angka 2018, katalog no.1102001.1601052, BPS, Palembang. Retrieved from https://okukab.bps.go.id/publication/2018/09/26/4936cbd29e684bc42b8724bc/kecamatan -lengkiti-dalam-angka-2018.html

Creswell, J.W. (2010). Research design: Pendekatan kualitatif, kuantitatif, dan mixed, Pustaka Pelajar, Yoyakarta.

Dinas Kehutanan Provinsi Sumatera Selatan. (2018). Buku risalah dan permasalahan pemanfaatan ruang kawasan hutan Provinsi Sumatera Selatan, Dinas Kehutanan Provinsi Sumatera Selatan, Palembang.

Direktur Jenderal Penataan Agraria. (2020). Potensi tanah objek reforma agraria (TORA), Disampaikan pada Rapat Pimpinan (RAPIM) Kementerian Agraria dan Tata Ruang/Badan Pertanahan Nasional, Jakarta, 4 MEI 2020.

Fisher, L. A., Kim, Y.-S., Latifah, S., \& Mukarom, M. (2017). Managing Forest Conflicts: Perspectives of Indonesia's Forest Management Unit Directors. Forest and Society, 1(1), 8-26.

http://dx.doi.org/10.24259/fs.v1i1.772 
Gunawan, H., \& Afriyanti, D. (2019). Potensi Perhutanan Sosial dalam Meningkatkan Partisipasi Masyarakat dalam Restorasi Gambut. Jurnal Ilmu Kehutanan, 13(2), 227-236. https://doi.org/10.22146/jik.52442

Hein, J., Adiwibowo, S., Dittrich, C., Rosyani, Soetarto, E., \& Faust, H. (2016). Rescaling of Access and Property Relations in a Frontier Landscape: Insights from Jambi, Indonesia, The Professional Geographer, 68(3): 380-389. https://doi.org/10.1080/00330124.2015.1089105

Irawan, A., Mairi, K., \& Ekawati, S. (2016). Analysis of Tenurial Conflict in Production Forest Management Unit (Pfmu) Model Poigar. Jurnal Wasian, 3(2), 79-90. https://doi.org/10.20886/jwas.v3i2.1595

Kane, S., Dhiaulhaq, A., Sapkota, L.M., Gritten, D., 2018, 'Transforming forest landscape conflicts: the promises and perils of global forest management initiatives such as REDD+', Forest and Society. 2(1), 1-17. http://dx.doi.org/10.24259/fs.v2i1.3203

Kawulich, B.B. (2005). 'Participant Observation as a Data Collection Method', FQS, Forum: Qualitative Social Research, 6(2): Art. 43. Retrieved from https://www.semanticscholar.org/paper/Participant-Observation-as-a-Data-CollectionMethod-Kawulich/940caae99bf625ce4dd16c246cce91dceb4bacfd

Konsorsium Pembaruan Agraria. (2018). Masa depan reforma agraria melampaui tahun politik, Konsorsium Pembaruan Agraria, Jakarta. Retrieved from http://kpa.or.id/publikasi/baca/laporan/30/Catahu_2018:_Masa_Depan_Reforma_Agraria_ Melampaui_Tahun_Politik/

LHK Minister Decree No. 180/MENLHK/SETJEN/KUM.1/4/2017 concerning State forests Allocation for Initiative Map for Provision Agrarian Reform Land Objects (TORA).

Luthfi, A. N. (2018). Reforma kelembagaan dalam kebijakan reforma agraria era Joko Widodo-Jusuf Kalla. BHUMI: Jurnal Agraria dan Pertanahan, 4(2), 140-163. https://doi.org/10.31292/jb.v4i2.276

Moeliono, M., Thuy, P.T., Bong, I.W., Wong, G.Y., \& Brockhaus, M. (2017). Social forestry-why and for whom? A comparison of policies in Vietnam and Indonesia, Forest and Society. 1(2), 7897. http://dx.doi.org/10.24259/fs.v1i2.2484

Muhsi, M.A. (2017). Legal Review Perhutanan Sosial, Multistakeholder Forestry Pragramme 3 (MFP3), Jakarta. Retrieved from https://id.scribd.com/document/406898107/Legal-ReviewPerhutanan-Sosial

Mulyadi, M. (2013). Pemberdayaan masyarakat adat dalam pembangunan kehutanan. Jurnal Penelitian Sosial dan Ekonomi Kehutanan, 10(4), 224-234. https://doi.org/10.20886/jpsek.2013.10.4.224-234

Nugroho, R. (2017). Penyelesaian penguasaan tanah dalam kawasan hutan di Kabupaten Lebak ditinjau dari Peraturan Presiden Nomor 88 Tahun 2017, Jurnal Pertanahan, 7(2), 61-73.

Nurbaya, S. (ed.) (2018). The State of Indonesia's forests, KLHK, Jakarta.

Pokharel, R.K., Neupane, P.R., Tiwari, K.R., \& Köhl, M. (2014). Assessing the sustainability in community based forestry: A case from Nepal, Forest Policy and Economics 58, 75-84. https://doi.org/10.1016/j.forpol.2014.11.006

Presidential Regulation Number 86/2018 concerning Agrarian Reform.

Presidential Regulation Number 88/2017 concerning Settlement of Land Tenure in State forests.

Pujo, P., Sofhani, T. F., Gunawan, B., \& Syamsudin, T. S. (2018). Community Capacity Building in Social Forestry Development: A Review. Journal of Regional and City Planning, 29(2), 113126. http://dx.doi.org/10.5614\%2Fjrcp.2018.29.2.3

Puspasari, E., Wulandari, C., Darmawan, A., \& Banuwa, I.S. (2017). Aspek sosial ekonomi pada sistem agroforestri di areal kerja Hutan Kemasyarakatan $(\mathrm{HKm})$ Kabupaten Lampung Barat, Provinsi Lampung, Jurnal Sylva Lestari. 5(3), 95-103. http://dx.doi.org/10.23960/jsl3595-103

Rachman, N.F. (2012). Land Reform dari masa ke masa, Tanah Air Beta dan Konsorsium Pembaruan Agraria (KPA), Yogyakarta. 
Rachman, N. F. (2014). Masyarakat Hukum Adat Adalah Bukan Penyandang Hak, Bukan Subjek Hukum, dan Bukan Pemilik Wilayah Adatnya. Wacana: Jurnal Ilmu-ilmu Sosial Transformatif, 33(16), 25-48.

Rachman, N.F (2017). Land reform \& gerakan agraria Indonesia, INSISTPress, Yogyakarta.

Raco, J.R. (2010). Metode penelitian kualitatif: Jenis, karakter dan keunggulannya, Grasindo, Jakarta.

Regulation of the Minister of Environment and Forestry of Republic of Indonesia Number P.17/MENLHK/ SETJEN/KUM.1/5/2018 concerning Procedures for the Release of State forests and Changes in the Limits of State forests for Land Sources for Agrarian Reform Objects.

Regulation of the Minister of Environment and Forestry of the Republic of Indonesia No.P.83/MENLHK/SETJEN/KUM.1/10/2016 concerning Social Forestry.

Regulation of the Coordinating Minister for the Economy of the Republic of Indonesia Number $3 / 2018$ concerning Guidelines for Implementing Duties of the Inventory and Verification Team for Land Tenure in State forests.

Rozi, Aa., Belvage, R., \& Karyanto, O. (2018). Konflik tenurial di Pulau Padang dan isolasi ekonomi lokal, Jurnal Sosiologi Pemikiran, 5(1). https://doi.org/10.22146/jps.v5i1.35402

Salim, M. N., Pinuji, S., \& Utami, W. (2018). Reforma Agraria di kawasan hutan Sungaitohor, Riau: pengelolaan Perhutanan Sosial di wilayah perbatasan. BHUMI: Jurnal Agraria dan Pertanahan, 4(2), 164-189. https://doi.org/10.31292/jb.v4i2.277

Salim, M.N., \& Utami W. (2019). Reforma agraria: Menyelesaikan mandat konstitusi. Kebijakan reforma agraria Joko Widodo dan perdebatan TORA. STPN Press, Yogyakarta.

Santun, D.I.M., Murni, \& Supriyanto. (2010). Iliran dan Uluan: Dikotomi dan dinamika dalam sejarah kultural Palembang. Eja Publisher. Yogyakarta.

Seixas, C. S., Davy, B., \& Leppan, W. (2009). Community-based conservation and development: Lessons learned from the 2004 Equator Prize. Canadian Journal of Development Studies/Revue canadienne d'études du développement, 28(3-4), 523-552. https://doi.org/10.1080/02255189.2009.9669228

Sirait, M.T. (2017). Inklusi, eksklusi dan perubahan agraria: Redistribusi tanah kawasan hutan di Indonesia, STPN Press, Yogyakarta.

Siscawati, M. (2014). Masyarakat adat dan perebutan penguasaan hutan, Wacana, Jurnal Transformasi Sosial, (33), 3-24.

Siscawati, M., Banjade, M. R., Liswanti, N., Herawati, T., Mwangi, E., Wulandari, C., Tjoa, M., \& Silaya, T. (2017). Overview of forest tenure reforms in Indonesia (Vol. 223). CIFOR. https://doi.org/10.17528/cifor/006402

Supriyanto, H., Jayawinangun, R., \& Saputro, B. (2017). Hutan kemasyarakatan hidup matinya petani miskin, Konsorsium KPSHK, Bogor.

Sutaryono (2018). Strategi percepatan penataan penguasaan tanah dalam kawasan hutan untuk reforma agraria di Kabupaten Bengkayang Kalimantan Barat: Studi di Desa Tiga Berkat dan Desa Suka Bangun, Laporan Hasil Penelitian Sistematis 2018, PPPM-STPN, Yogyakarta.

Sutaryono, Arianto, T.A., \& Luthfi, A.N. (2018). Hubungan negara dan masyarakat sipil dalam kebijakan reforma agraria dan penyelesaian permasalahan tanah dalam kawasan hutan di Kabupaten Sigi', Laporan Hasil Penelitian Sistematis 2018, PPPM-STPN, Yogyakarta.

Tim Pelaksana PPTKH/Penyelesaian Penguasaan Tanah dalam Kawasan Hutan. (2017). 'Sosialisasi Peraturan Presiden Nomor 88 Tahun 2017 Tentang Penyelesaian Penguasaan Tanah dalam Kawasan Hutan', Kementerian Koordinator Bidang Perekonomian Republik Indonesia, Jakarta.

Utami, W., Salim, M.N. \& Mujiati. (2018). Tanah Obyek Reforma Agraria (TORA) pelepasan kawasan hutan', Laporan Hasil Penelitian Sistematis 2018, PPPM-STPN, Yogyakarta. 
van der Muur, W. (2018). Forest conflicts and the informal nature of realizing indigenous land rights in Indonesia. Citizenship studies, 22(2), 160-174. https://doi.org/10.1080/13621025.2018.1445495

Wibowo, A., Arman, M., Vitasari, D.M., Cahyadi, E., Kristianto, E.D., Chaakimah, S., Murdiningrum, Y.A., Malik, \& Indyanto, T. (2017). Dari reformasi kembali ke Orde Baru: Tinjauan kritis Peraturan Presiden No. 88 Tahun 2017, Opini Hukum, X, 1-6.

Wibowo, A. (2019). Asal usul kebijakan pencadangan Hutan Adat di Indonesia. BHUMI: Jurnal Agraria dan Pertanahan, 5(1), 26-41. https://doi.org/10.31292/jb.v5i1.317

Winata, D.K. (2019). KLHK identifikasi ribuan desa di kawasan hutan', Media Indonesia, 10 Maret, Retrieved from https://mediaindonesia.com/read/detail/221945-klhk-identifikasi-ribuandesa-di-kawasan-hutan.

Yunus, H.S. (2010). Metodologi penelitian wilayah kontemporer, Pustaka Pelajar, Yogyakarta. 